\title{
Detection of IgA antibody to EBV membrane antigen using Staphylococcus aureus preabsorbed sera is closely associated with nasopharyngeal carcinoma
}

\author{
G.H. $\mathrm{Pi}^{1}, \mathrm{Y}$. Zeng $^{1}$ and $\mathrm{H}$. Wolf ${ }^{2}$ \\ 'Chinese National Center for Preventive Medicine, Institute of Virology, 100 Ying Xing Jie, Xuan Wu \\ Qu, 100052 Beijing, China, and ${ }^{2}$ Max von Pettenkofer-Institut, Ludwig-Maximilians-Universität, \\ Pettenkoferstrasse $9 a, 8000$ Munich 2, F.R.G.
}

(Accepted 16 August 1986)

The presence of $\operatorname{IgA}$ antibody to membrane antigen (MA) of Epstein-Barr virus (EBV) was tested in sera from 48 nasopharyngeal carcinoma (NPC) patients, 40 patients with tumors other than NPC and 46 normal individuals. The sera were preabsorbed with Staphylococcus aureus (SPA) (strain no. 1800) prior to their use in the indirect immunofluorescence test. One hundred percent of the NPC patients had the IgA/MA antibody with a GMT of 1:141. In patients with tumors other than NPC or normal individuals, $\operatorname{IgA} / \mathrm{MA}$ antibodies were not detectable. The $\mathrm{IgA} / \mathrm{MA}$ antibodies have been demonstrated in 6 NPC patients lacking detectable antibody levels in the indirect immunofluorescence test using nonabsorbed sera. Our data indicate that preabsorbtion of sera with SPA renders the diagnostic test significantly more sensitive for the detection of the nasopharyngeal carcinoma and can be used for trials on the prognosis of patients.

Nasopharyngeal carcinoma; Epstein-Barr virus; IgA/MA antibody; Staphylococcus aureus

\section{Introduction}

Klein et al. (1966) first reported the presence of the membrane antigen (MA) of Epstein-Barr virus (EBV) in cell lines established from Burkitts lymphoma (BL) by indirect immunofluorescence tests and demonstrated the EBV specificity of MA using a direct blocking test (Klein et al., 1969). The antibodies to EBV-MA in sera from nasopharyngeal carcinoma (NPC) patients were tested (De Schryver et al., 1969; Zhu et al., 1986). For the IgA/MA antibody, 58.3\% of NPC patients were positive with a GMT of 1:7.3 and none of the normal individuals were positive.

Correspondence to: $\mathrm{H}$. Wolf, Max von Pettenkofer-Institut, Ludwig-Maximilians-Universität, Pettenkoferstrasse 9a, 8000 Munich 2, F.R.G. 
The detection of IgA/MA antibodies appeared to be specific for NPC, but not as sensitive as the detection of $\operatorname{lgA} / \mathrm{EA}$ which allowed detection rates of up to $70 \%$ (Zeng et al., 1983a). It is therefore necessary to improve the sensitivity of this test for the detection of the IgA/MA antibody. Here we report on a new technique and its application for detection of the $\operatorname{IgA} / \mathrm{MA}$ antibody in NPC patients.

\section{Materials and Methods}

Sera

Sera were taken from 48 NPC patients, 40 patients with tumors other than NPC and 46 normal individuals, and stored at $-20^{\circ} \mathrm{C}$.

\section{Procedure}

The target cells used for detection of the IgA/MA antibody were B95- 8 cells, activated for 24 h by $n$-butyrate $(4 \mathrm{mM})$ and croton oil $(500 \mathrm{ng} / \mathrm{ml})$. The activated cells were washed 3 times with Hank's solution and adjusted to $2 \times 10^{6}$ cells $/ \mathrm{ml}$. $110^{5}$. cells in $50 \mu \mathrm{l}$ were added to each well of 96 well $\mathrm{U}$-shaped hemagglutination plates.

Serum samples were treated prior to titration in the following manner: $25 \mathrm{ml}$ of each serum was diluted 1:5 by adding $25 \mu \mathrm{l}$ Staphylococcus aureus (SPA) (10\% suspension of formalin inactivated bacteria; Kessler, 1975) and $7.5 \mu$ l Hank's solution. The mixtures were incubated at $37^{\circ} \mathrm{C}$ for $1 \mathrm{~h}$ and then centrifuged at $3000 \mathrm{rpm}$ for $20 \mathrm{~min}$. The supernate was considered 1:5 diluted and was further diluted from 1:10 to 1:1280 in 2-fold dilution steps. $50 \mu \mathrm{l}$ of each dilution of serum were added to each well with target cells. The plates were incubated in a humid chamber at $37^{\circ} \mathrm{C}$ for $45 \mathrm{~min}$. After washing 3 times with Hank's solution, the incubated cells were smeared on special Teflon-coated slides with clear areas, air dried and fixed with cold acetone. 1:10 diluted sheep anti-human $\operatorname{IgA}$ antibody conjugated with FITC was added and the slides were kept at $37^{\circ} \mathrm{C}$ for $45 \mathrm{~min}$. The cell smears were again washed 3 times with 0.01 M PBS (pH 7.6). After counter-staining with $0.006 \%$ Evans blue for $10 \mathrm{~min}$, they were examined under an Olympus fluorescence microscope. The cell membrane stained with specific green color was considered to be positive.

\section{Immunoenzymatic test}

The test was done as described by Zeng et al. (1979).

\section{Results}

Comparison of positive rates of IgA antibodies to VCA, EA and MA in sera from NPC patients and control groups

Sera from 48 NPC patients, from 40 patients with tumors other than NPC and from 46 normal individuals were tested for EBV, $\lg A / E A$ and $\lg A / V C A$ antibod- 


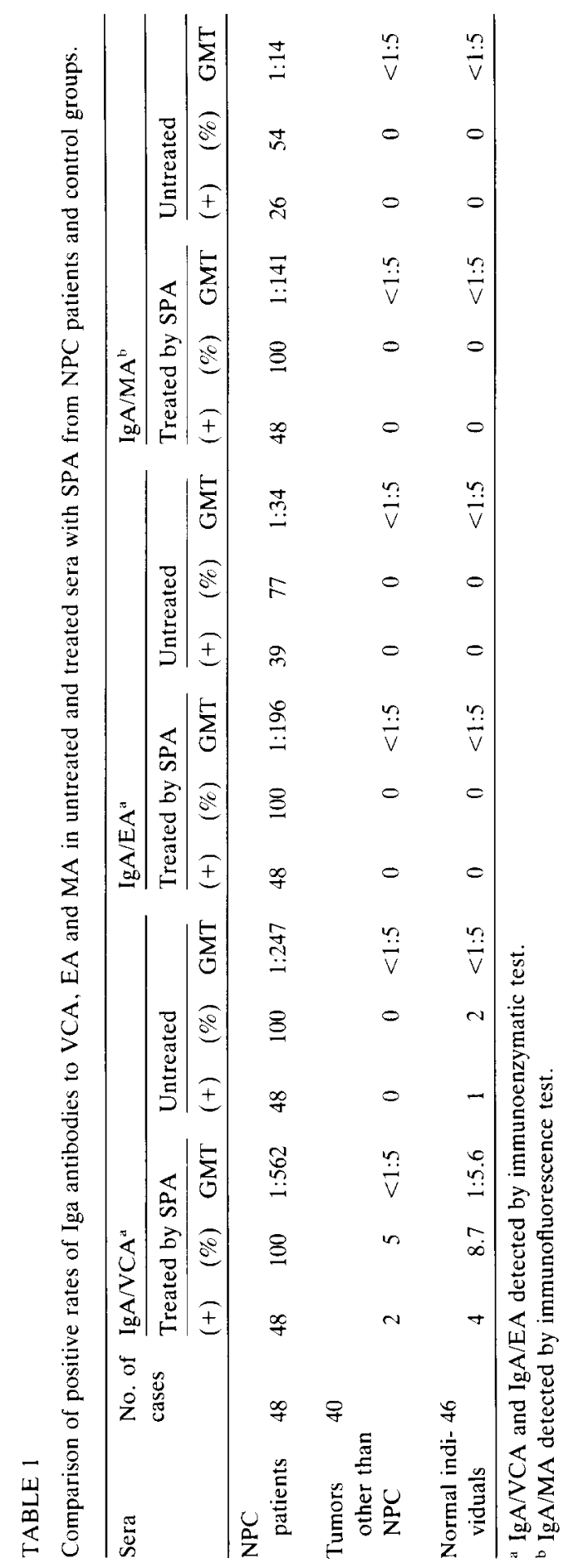


TABLE 2

Comparison of the sensitivity of untreated and treated sera with SPA by indirect immunofluorescence method.

\begin{tabular}{lll}
\hline Sera from NPC patients & \multicolumn{2}{l}{ IgA/MA antibody titers of sera } \\
\cline { 2 - 3 } & Treated by SPA & Untreated \\
\hline 2772 & $1: 20$ & $<5$ \\
2573 & $1: 20$ & $<5$ \\
2519 & $1: 40$ & $<5$ \\
2549 & $1: 80$ & $<5$ \\
2760 & $1: 80$ & $<5$ \\
2770 & $1: 80$ & $<5$ \\
2771 & $1: 160$ & $1: 10$ \\
2765 & $1: 160$ & $1: 20$ \\
2753 & $1: 320$ & $1: 20$ \\
2747 & $1: 320$ & $1: 80$ \\
2740 & $1: 640$ & $1: 80$ \\
2794 & $1: 640$ & $1: 320$ \\
\hline GMT & $1: 120$ & $1: 15$ \\
\hline Normal individuals & & \\
\hline 3651 & $<5$ & $<5$ \\
3644 & $<5$ & $<5$ \\
3674 & $<5$ & $<5$ \\
3652 & $<5$ & $<5$ \\
3649 & $<5$ & $<5$ \\
3641 & $<5$ & $<5$ \\
3660 & $<5$ & $<5$ \\
3658 & $<5$ & $<5$ \\
3659 & $<5$ & $<5$ \\
3647 & $<5$ & $<5$ \\
\hline & &
\end{tabular}

ies with the immunoenzymatic test and for IgA/MA antibodies with IF using sera untreated or preabsorbed with SPA, respectively. The results are given in Table 1.

Specificity and sensitivity of the modified method

Previous studies (Zhu et al., 1986) have detected IgA/MA antibodies in only $58.3 \%$ of NPC cases. In order to test whether competing IgG antibodies in the remaining $41.7 \%$ of sera were responsible for the negative results for $\operatorname{IgA} / \mathrm{MA}$ antibodies, sera from 12 NPC patients and 10 normal individuals were tested in parallel using nonabsorbed and SPA-preabsorbed sera, respectively.

As seen in Table 2, the GMT of the IgA/MA antibody titers were 8 times higher in preabsorbed sera. Antibody titers of 1:160 and higher were found in $50 \%$ of the preabsorbed sera group but only in one of the 12 nonabsorbed sera. There is no positive result in preabsorbed sera from normal individuals. A good correlation between antibody titers detected by the modified method and the immunoenzymatic test was obtained (Fig. 1). In most NPC cases, the antibody titers for IgA/VCA were higher than for IgA/MA (Fig. 2). 


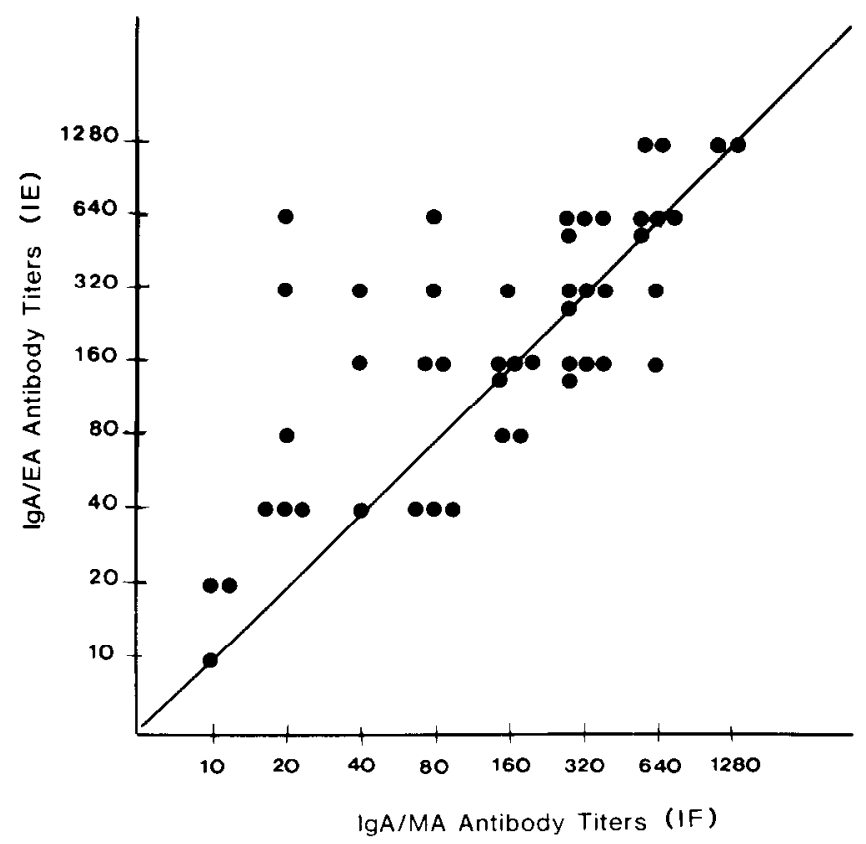

Fig. 1. Relationship between IgA/MA and IgA/EA antibodies in sera from NPC patients as detected by the immunoenzymatic test.

\section{Discussion}

Serological mass surveys were carried out in Zangwu County of the Guangxi Autonomous Region in populations with a high risk of developing NPC. The results indicate that the detection of IgA antibodies to VCA and F.A of FBV is valuable for early diagnosis of NPC (Zeng et al., 1979; Zeng et al., 1980; Zeng et al., $1983 \mathrm{a}, \mathrm{b}) .58 .3 \%$ of the NPC patients were found to have $\operatorname{IgA} / \mathrm{MA}$ antibodies, whereas all normal individuals lacked IgA antibodies to this antigen. The situation is similar for IgA/EA antibodies (Zeng et al., 1983a), suggesting that detection of the IgA/MA antibody could be used as a marker for the diagnosis of NPC.

However, the detection of EBV IgA/MA antibodies did not seem to be as sensitive for the diagnosis of NPC as IgA/VCA antibodies. Here we demonstrated that the rate of detection of IgA antibodies to EBV-MA by preabsorbing sera with SPA was drastically increased. Forsgren et al. (1966) first reported that SPA can bind to the FC sequence of $\operatorname{IgG}$, but it is hardly effective in removing IgA from serum.

The limited concentration of antigen in the cells used for the fluorescence test is apparently competitively blocked by the usually high levels of IgG/MA. Thus, the removal of an excess of IgG yielded an enormous increase of sensitivity without increasing nonspecific reactions.

This very sensitive test for detection of NPC is easy to perform, reproducible, 


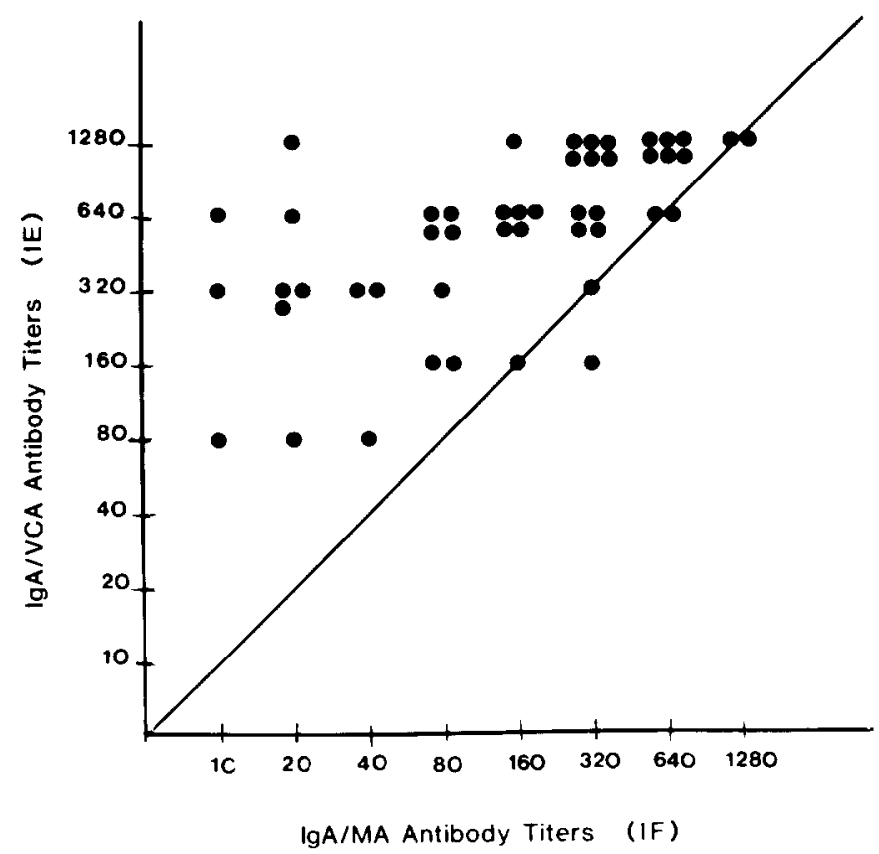

Fig. 2. Relationship between IgA/MA and IgA/VCA antibodies in sera from NPC patients (IE = immunoenzymatic test, IF = immunofluorescence test).

and can be used for initial diagnosis and for follow-up studies (therapy control) of NPC patients. Because recombinant MA is becoming available (Motz et al., 1986; Motz et al., in preparation), this test should soon be available for mass screening.

\section{References}

De Schryver, A., Friberg, Jr., S., Klein, G., Henle, W., Henle, G., de The, G., Clifford, P. and Ho, H.C. (1969) Epstein-Barr virus-associated antibody patterns in carcinoma of the post-nasal space. Clin. Exp. Immunol. 5, 443-459.

Forsgren, A. and Sjöquist, J. (1966) 'Protein A' for S. aureus I. pseudo-immune reaction with human rg-globulin. J. Immunol. 97, 822.

Kessler, S.W. (1975) Rapid isolation of antigens from cells with a staphylococcal protein A-antibody adsorbent: parameters of the interaction of antibody-antigen complexes with protein $\mathrm{A}^{1}$. J. Immunol. 115, 1617-1624.

Klein, G., Clifford, P., Klein, E. and Stjernswärd, J. (1966) Search for tumor-specific immune reaction in Burkitt's lymphoma patients by the membrane immunofluorescence reaction. Proc. Natl. Acad. Sci. U.S.A. 55, 1628-1635.

Klein, G., Pearson, G., Henle, G., Henle, W., Goldstein, G. and Clifford, P. (1969) Relation between Epstein-Barr viral and cell membrane immunofluorescence in Burkitt's lymphoma tumor cells. 1. Exp. Med. 129, 678-705.

Motz, M., Deby, G., Jilg, W. and Wolf, H. (1986) Expression of the Epstein-Barr virus major membrane proteins in Chinese hamster ovary cells. Gene, in press.

Zeng, Y., Yuxi, L., Chunren, L., Sanwen, C., Jineng, W., Jison, Z. and Huijong, Z. (1979) Appli- 
cation of an immunoenzymatic method and an immunoautoradiographic method for a mass survey of nasopharyngeal carcinoma. Chin. J. Oncol. 1, 2.

Zeng, Y., Lin, Y.X., Wei, J.N., Zhu, J.S., Cai, S.L., Wang, P.Z., Zhong, J.M., Li, R.C., Pan, W.C., Li, E.J. and Tan, B.F. (1979) Serological mass survey of nasopharyngeal carcinoma. Acta Acad. Med. Sci. 1, 123-126.

Zeng, Y., Lui, Y.. Liu, C., Chen, S., Wei, J., Zhu, J. and Zai, H. (1980) Application of an immunoenzymatic method and an immunoautoradiographic method for a mass survey of nasopharyngeal carcinoma. Intervirology 13, 162-168.

Zeng, Y., Zhong, L., Li, P., Wang, P., Tang, Y.R., Ma, Y.R., Zhu, J.S., Pan, W.J., Liu, Y.X., Wei, Z.N., Chen, J.Y., Mo, Y.K., Li, E.J. and Tan, B.F. (1983a) Follow-up studies on Epstein-Barr virus IgA/VCA antibody positive persons in Zangwu County, China. Intervirology 20, 190-194.

Zeng, Y., Gong, C., Jan, M. . Fun. Z., Zhong, L. and Li, J. (1983b) Detection of Fpstein-Barr virus IgA/EA antibody for diagnosis of nasopharyngeal carcinoma by immunoautoradiography. Int. J. Cancer 31, 599-601.

Zhu, X.X., Zeng, Y. and Wolf, H. (1986) Detection of IgG and IgA antibodies to Epstein-Barr virus membrane antigen in the sera from patients with nasopharyngeal carcinoma and normal individuals. Int. J. Cancer 37, 689-691. 